Bull. Fac .Agric., Cairo Univ. 67:167-179 (2016).

\title{
PRODUCTION OF GLUTEN- FREE ROLLED PAPERS FROM BROKEN RICE BY USING DIFFERENT HYDROTHERMAL TREATMENTS
}

\author{
(Received:5.5. 2016)
}

\author{
By \\ A.M. H. Abdel-Haleem \\ Crops Technology Research Department, Food Technology Research Institute , \\ Agricultural Research Center, Giza, Egypt.
}

\begin{abstract}
The aim of this study was to produce gluten- free rolled papers from broken rice by using different hydrothermal treatments. Pressure parboiling, dry roast parboiling, and popping treatments were applied to enhance the functionality of low- amylose broken rice flour. The effects of hydrothermal treatments on the morphological, physicochemical, as well as sensory properties of the produced gluten- free rolled papers were studied. Morphological examination of hydrothermal treated flours showed gelatinized and enlarged starch granules with different shapes, and fractures in the surface, especially in dry roasted parboiled flour. For chemical composition (g/100g), protein (6.73.57), total starch (81.67- 76.36) and amylose (17.27- 14.18) significantly decreased in rice papers produced from hydrothermal treated flours, while fat (1.67- 1.82) and ash (1.62- 2.68) significantly increased. In vitro starch digestibility showed a significant increase (80-99.73 g glucose/ $100 \mathrm{~g}$ ) in rice papers produced from dry roast parboiling and popping treatments. Rice paper batters produced from hydrothermal treatments had a noticeable viscosity pattern characterized by a non-Newtonian pseudoplastic flow behavior. A significant reduction in lightness value (89.77 to 60.42) occurred, while a significant increase in redness (0.33 to 1.54$)$ and yellowness (3.75- 20.59) values were observed in all rice papers produced from hydrothermal- treated flours. Tensile strength (0.14- 0.36 $\mathrm{N} / \mathrm{mm}^{2}$ ) and \% elongation at break (43- 57\%) significantly increased in rice papers produced from parboiling treatments, while fracture toughness increased $\left(2.76-5.51 \mathrm{~N} / \mathrm{mm}^{3 / 2}\right)$ in rice paper produced from popping treatment. Sensory evaluation indicated significant improvement in freshness, rollability, and the overall scores in rice papers produced from parboiling treatments. Results could be a value addition for processing of low- amylose broken rice flour and delivering high quality rice papers to consumers who are more concerned about gluten- free products.
\end{abstract}

Key words: Rice paper, Heat treatments, Morphological examination, Physicochemical properties, Sensory evaluation.

\section{INTRODUCTION}

Nowadays, the motivation for improving and developing gluten-free foods have attracted much research interest (Rosell et al., 2014). Especially with rising number of patients with gluten sensitivity and celiac disease (Lebwohl et al., 2015), in addition to the rapid change in consumer lifestyle, where gluten-free diet is also associated with weight management and overall health (Lamacchia et al., 2014; Murray et al., 2015).

Broken rice is a by-product produced during rice milling and polishing (Marco et al., 2014). It has been used in the manufacturing of rice flour and modified starches, with the advantages of low cost and great availability, as a value addition to various industrial utilization (Limberger et al., 2008; Bhatnagar et al., 2014; Ashour et al., 2015). Rice flour is a suitable ingredient to prepare gluten-free products, because of its tender taste, white color, easily digestible carbohydrates, and hypoallergenic activities (Rosell et al., 2014; Loubes et al., 2016).

Rice paper based on rice flour or rice starch is a common food in East Asian and Southeast Asian cuisine, particularly in Vietnam and Thailand, and is gaining popularity in North America (Cameron and Hosseinian, 2013). But, 
it is not popular in Arab countries, especially in Egypt. Rice paper is a large variety of filled, rolled appetizers as spring roll papers (Nagano et al., 2000) or güllac/golash produced from wheat flour. The type of wrapper, fillings, and the cooking method used, as well as the name, differ considerably inside this large zone, according to the culture of the area (Phothiset and Charoenrein, 2007).

Manufacturing of rice paper from Egyptian rice varieties (Japonica type) and its byproducts might confront a challenge relates to the lower- amylose content of these varieties. These varieties are the most widespread and preferable by the Egyptian consumer due to its cooking and eating characteristics, e.g. moistness , tenderness, glosses and taste (El-Hissewy et al., 1992; Oko et al., 2012). However, flour from low-amylose rice has no potential for making usable rice papers (Nagano et al., 2000; Jobling, 2004). Besides, problems related to rice flour quality, where native rice flour has poor resistance to shear force, and low elastic gel-forming ability. Also, most native starches have a marked tendency to lose their viscosity and thickening power during cooking (Pitiphunpong and Suwannaporn, 2009; Cham and Suwannaporn, 2010; Colussi et al., 2014).

Different hydrothermal treatments have been successfully applied to enhance the physicochemical and functionality of rice flours and starches (Cham and Suwannaporn, 2010; Dutta et al., 2015). Parboiling technique is a hydrothermal process consisting of soaking, heating and drying operations modifying the qualitative and processing behavior of rice flour (Dutta and Mahanta, 2012; Shittu et al., 2012). On parboiling, the starch granules are gelatinized, retrograded, and considerable changes occur in the pasting parameters due to the order-disorder transitions taking place at the molecular level (Zhu et al., 2010; Dutta and Mahanta, 2012). These changes play an important role in the subsequent processing operations, such as, cooking and eating qualities (Patindol et al., 2008; Mir and Bosco, 2013). Popping in the presence of salt solutions is another hydrothermal treatment. During popping gelatinization and drying occur simultaneously, and the popped products are characterized by good texture, highly desirable aroma, taste and acceptability (Livingstone et al., 1993; Mishra et al., 2014).

However, despite the possibilities of applying the hydrothermal treatments for enhancement the functions of the rice flours, these treatments have never been studied for the production of rice papers. Therefore, the aim of the present study was to produce gluten- free rolled papers from low- amylose broken rice flour by using hydrothermal treatments namely; pressure parboiling; dry roast parboiling and popping, to enhance the functionality of the broken rice flour. Besides, studying the effects of these hydrothermal treatments on the morphological, physicochemical, as well as sensory properties of the produced gluten- free rolled papers.

\section{MATERIALS AND METHODS \\ 2.1Materials}

Broken rice from low amylose $(15.27 \%)$ rice variety Sakha 104 (Japonica genotype) was obtained after the milling and polishing process of brown rice, local milling processing unit, Damietta, Egypt. The percentage of broken to rice kernel was $27 \%$. Corn starch, corn oil, salt, soft white salty cheese, peppermint and vanilla were purchased from the supermarket, Al-Giza, Egypt. Pancreatic $\alpha$ - amylase (1: 2000 activity) was obtained from Oxford Lab. Chem, India. Amyloglucosidase (amylo 300) was obtained from Biocon India (Pvt. Ltd., India). Amylose and $D$ - glucose standards were obtained from Sigma- Aldrich,(St. Louis, MO, USA.) A glucose oxidase/ peroxidase kit was obtained from Biodiagnostic Co.,(Al-Giza, Egypt). All other chemicals used were of analytical reagent grade.

\subsection{Methods}

\subsubsection{Hydrothermal treatments of broken rice 2.2.1.1.Pressure parboiling treatment of broken rice}

The pressured parboiled broken rice was prepared as described by Chinnaswamy and Bhattacharya (1986). About one $\mathrm{kg}$ of broken rice was soaked in double amount of water for $30 \mathrm{~min} / 37^{\circ} \mathrm{C}$, then water was drained-off, and broken rice was spread on a wire mesh tray and steamed in an autoclave at $121{ }^{\circ} \mathrm{C} / 20 \mathrm{~min}$ under a pressure steaming of 15 psi. Soaking was performed in triplicate. Pressured parboiled broken rice was dried at $40^{\circ} \mathrm{C}$ in an air convection oven till dry.

\subsubsection{Dry roast parboiling treatment of broken rice}

Dry roasted parboiled broken rice was prepared as described by Shashikala et al. (2005). About one $\mathrm{kg}$ of broken rice was soaked in water $(1: 10)$ at $\sim 98^{\circ} \mathrm{C}$ (the temperature after 
mixing was $70{ }^{\circ} \mathrm{C}$ ). The container was well covered to allow slow cooling for $18 \mathrm{~h}$. Soaking was performed in triplicate. The water was drained, and the parboiled broken rice was roasted at $165^{\circ} \mathrm{C} / 3 \mathrm{~h}$ in an air convection oven. Then the temperature was reduced to $40^{\circ} \mathrm{C}$ until drying.

\subsubsection{Popping treatment of broken rice}

The popped broken rice was obtained by modifying the method of Hsieh and Bor (1991). About one $\mathrm{kg}$ of broken rice was conditioned from initial moisture content $10.9 \%$ to moisture level from $14-14.5 \%$ by adding a measured amount of water $(42 \mathrm{ml})$ containing salt solution (2 $\mathrm{g}$ salt/ $100 \mathrm{ml}$ water), then tempered overnight in an airtight container at room temperature. Conditioning was performed in triplicate. It was then subjected to high temperature $220^{\circ} \mathrm{C} / 2 \mathrm{~min}$ in a convection hot air popping maker (Ĥome PM-1891, $1200 \mathrm{~W}$, 220 V, 50 HZ, China).

\subsubsection{Milling of broken rice samples}

Untreated and hydrothermal treated broken rice samples were milled with laboratory hammer mill and sieved through $850 \mu \mathrm{m}$ sieve. The produced flours were kept in plastic bags at room temperature for further use.

\subsubsection{Scanning Electron Microscopic (SEM) examination}

Morphology of untreated and hydrothermal treated broken rice flours were examined using Scanning Electron Microscope (SEM) according to Dronzek et al. (1972). Samples were sputtercoated (SPI- Module ${ }^{\mathrm{TM}}$ Sputter Coater, USA) with gold at vacuum evaporator then examined using SEM (JEOL, JSM- 5200, Tokyo, Japan) at $25 \mathrm{kV}$ accelerating voltage with different magnification power at 500, 750,1000 and $5000 X$

\subsubsection{Production of gluten- free rolled papers}

Gluten- free rolled papers were prepared from untreated and hydrothermal- treated broken rice flours according to Cameron and Hosseinian (2013). The proper composition to formulate the batter were broken rice flour $(64 \mathrm{~g} / 100 \mathrm{~g})$, corn starch (30 g/100 g), corn oil (3.5 g/ $100 \mathrm{~g})$, salt $(2 \mathrm{~g} / 100 \mathrm{~g})$, vanilla $(0.5 \mathrm{~g} / 100 \mathrm{~g})$, and water. The batter was mixed with whisk till proper consistency, spread thinly with a ladle on a tightly stretched cloth, then covered with a lid and steamed for $1-2 \mathrm{~min} / 80^{\circ} \mathrm{C}$ over a water bath. The rice paper skins were allowed to cool and kept in plastic film to make the sensory evaluation and mechanical properties. The rest of rice paper skins were dried at ambient temperature for $18 \mathrm{~h}$, milled and kept in plastic bags at $5^{\circ} \mathrm{C}$ for further analysis.

\subsubsection{Proximate analysis}

Moisture, protein, fat, crude fiber, and ash contents of the broken rice and the rice papers prepared from untreated and hydrothermaltreated flours were determined according to the methods of AOAC (2007). The nitrogen content was estimated by Kjeldahl method, and the nitrogen conversion factor of the crude protein calculation was 5.75 . The amylose content was determined according to the method of Juliano (1971) based on the blue color reaction with iodine. The results were expressed on a dry basis, and all analyses of different samples were averaged from three replicates.

\subsubsection{In vitro starch digestibility and total starch}

In vitro starch digestibility of the broken rice flour and gluten- free rice papers were determined using pancreatic amylase and amyloglucosidase according to the modified method of Englyst et al. (1992). A suitable amount of defatted sample $(0.5 \mathrm{~g})$ was dispersed in $30 \mathrm{ml}$ of $0.2 \mathrm{M}$ sodium acetate buffer, $\mathrm{pH} 6.0$. Freshly prepared solution of pancreatic $\alpha$ amylase and amyloglucosidase $(5 \mathrm{ml})$ was added to the sample suspension and incubated at $37^{\circ} \mathrm{C} /$ 20 then $120 \mathrm{~min}$. The obtained aliquots $(0.5 \mathrm{ml})$ were mixed with $4 \mathrm{ml} 80 \%$ ethanol and centrifuged at $4000 \times \mathrm{g} / 10 \mathrm{~min}$. The glucose in the mixture was measured using glucose oxidase/ peroxidise assay and standard curve of $D$ - glucose. Total starch was estimated following the same procedure using amyloglucosidase only. The glucose released (g/ $100 \mathrm{~g}$ ) was calculated using the following equation:

Glucose released $(\mathrm{g} / 100 \mathrm{~g})=$

$\frac{\text { total weight of glucose in supernatant } \times 0.9}{\text { dry weight of starch }} \times 100$

where 0.9 is the molar mass conversion from glucose to the starch monomer unit.

\subsubsection{Viscoelastic properties of the gluten- free rice paper batters}

Viscoelastic properties of the gluten-free rice paper batters were measured using Brookfield Engineering labs DV-III Ultra Rheometer as indicated in Brookfield Manual (1998). The sample was placed into a small adapter at $37^{\circ} \mathrm{C}$, and the SC4-21 spindle was selected for the measurement. The Viscometer was operated between 10 and 60 RPM. Apparent viscosity and shear rate data were obtained directly from the instrument. 


\subsubsection{Color measurements of gluten- free rice papers}

The colorimetric measurements of glutenfree rice papers were measured in triplicate using a colorimeter (CR-10, Konica Minolta Sensing Inc., Japan) according to McGurie (1992). The color values were recorded as $L^{*}=$ lightness $(0=$ black, $100=$ white $), a^{*}\left(-a^{*}=\right.$ greenness, $+a^{*}=$ redness $)$ and $b^{*}\left(-b^{*}=\right.$ blueness, $+b^{*}=$ yellowness).

\subsubsection{Mechanical properties of gluten- free rice papers}

The mechanical properties of the gluten- free rice papers were tested using a texture analyzer Universal Testing Machine, (Cometech, Taiwan), according to the method of ASTM D882 (2010). Gluten- free rice paper samples were cut into small strips, $3 \mathrm{~cm} \mathrm{x} 1 \mathrm{~cm}$ and the measurement of each strip averaged from 5 replicates. The ends of the strips were clamped between cardboard grips using double-side adhesive tape such that the final area exposed was $25.4 \mathrm{~mm} \times 50.0 \mathrm{~mm}$ with a load cell of 25 $\mathrm{kg}$. The initial grip separation of the tensile mode was set at $50 \mathrm{~mm}$, and force $(\mathrm{N})$ and elongation $(\mathrm{mm})$ were recorded during extension at $20 \mathrm{~mm} / \mathrm{min}$ up to break. From the resulting forced- time curve, tensile strength $\left(\mathrm{N} / \mathrm{mm}^{2}\right)$, elongation at break $(\mathrm{E} \%)$, and fracture toughness $\left(\mathrm{N} / \mathrm{mm}^{3 / 2}\right)$ were calculated.

\subsubsection{Sensory evaluation of gluten-free rolled papers}

Gluten- free rolled papers were prepared with a filling containing white cheese and peppermint paste, glazed with butter and baked in an oven grill till golden surface appeared. A 9-point hedonic scale was used for determining the sensory evaluation for color, taste, aroma, firmness, freshness, rollability and overall liking of gluten- free rolled papers. The sensory evaluation of samples was conducted according to Cameron and Hosseinian (2013). A ten member sensory panel was formed from the staff of Food Technology Research Institute, Agricultural Research Center, Al- Giza- Egypt. All samples were coded with three-digit random numbers and presented to panelists on a tray at ambient temperature. Orders of servings were completely randomized. Rollability liking score was performed on unbaked samples by how easy a sample is wrapped or rolled and filled with cheese and peppermint paste without tearing. For each sample, panelists scored their liking of these characteristics using the 9-point hedonic scale $(1=$ dislike extremely, $5=$ neither like nor dislike and $9=$ like extremely). An average of 10 scores for each attribute was reported.

\subsubsection{Statistical analysis}

All data were subjected to analysis of variance. Duncan 's multiple range tests at $(P \leq 0.05)$ level to compare between means. The analysis was carried out using the PRO ANOVA procedure of SAS Program (1996).

\section{RESULTS AND DISCUSSION} 3.1.Scanning Electron Microscopic (SEM) examination of untreated and hydrothermal treated flours

Figure (1) presents the morphological examination of untreated and hydrothermal treated flours obtained by SEM. As shown in Fig.(1) starch granules had smaller sizes, appeared to be compactly packed in untreated flour. In pressure parboiled flour, the starch granules seem to be partially gelatinized (Chang and Yang, 1992). In dry roasted parboiled flour, the starch granules were the most expanded, smooth and had polygonal and angular shapes. Besides, some fracture on starch granule surface. This might be a result of parboiling followed by roasting treatment used in the modification method, which caused swollen or gelatinized granules around the surface (Lorlowhakarn and Naivikul, 2006). In popped flour, the starch granules had variable sizes, randomly located, gradually gelatinized and melted substance appeared. This might be when samples were suddenly subjected to a very high temperature, the water in the soaked broken rice simultaneously participated in starch gelatinization as well as tried to evaporate out of the starch granules in all possible directions, causing rapid drying of the gelatinized granules (Bhattacharya and Ali, 1985; Dutta et al., 2015; Wongsa et al., 2016).

3.2. Chemical composition of broken rice flour and untreated and hydrothermal treated gluten- free rice papers

Table (1) represents the chemical composition of broken rice flour and rice papers produced from untreated and hydrothermal treated flours on dry weight basis.

It could be noticed that broken rice flour had $7.40 ; 0.47 ; 0.49 ; 0.73 ; 84.81$ and $15.27 \mathrm{~g} / 100 \mathrm{~g}$ for protein; fat; ash; crude fiber, total starch, and amylose, respectively.

Although, the value of broken rice is lower than whole kernel (Bhattacharya, 2004), but broken rice has the same chemical composition as the polished one (Marco et al., 2014). 

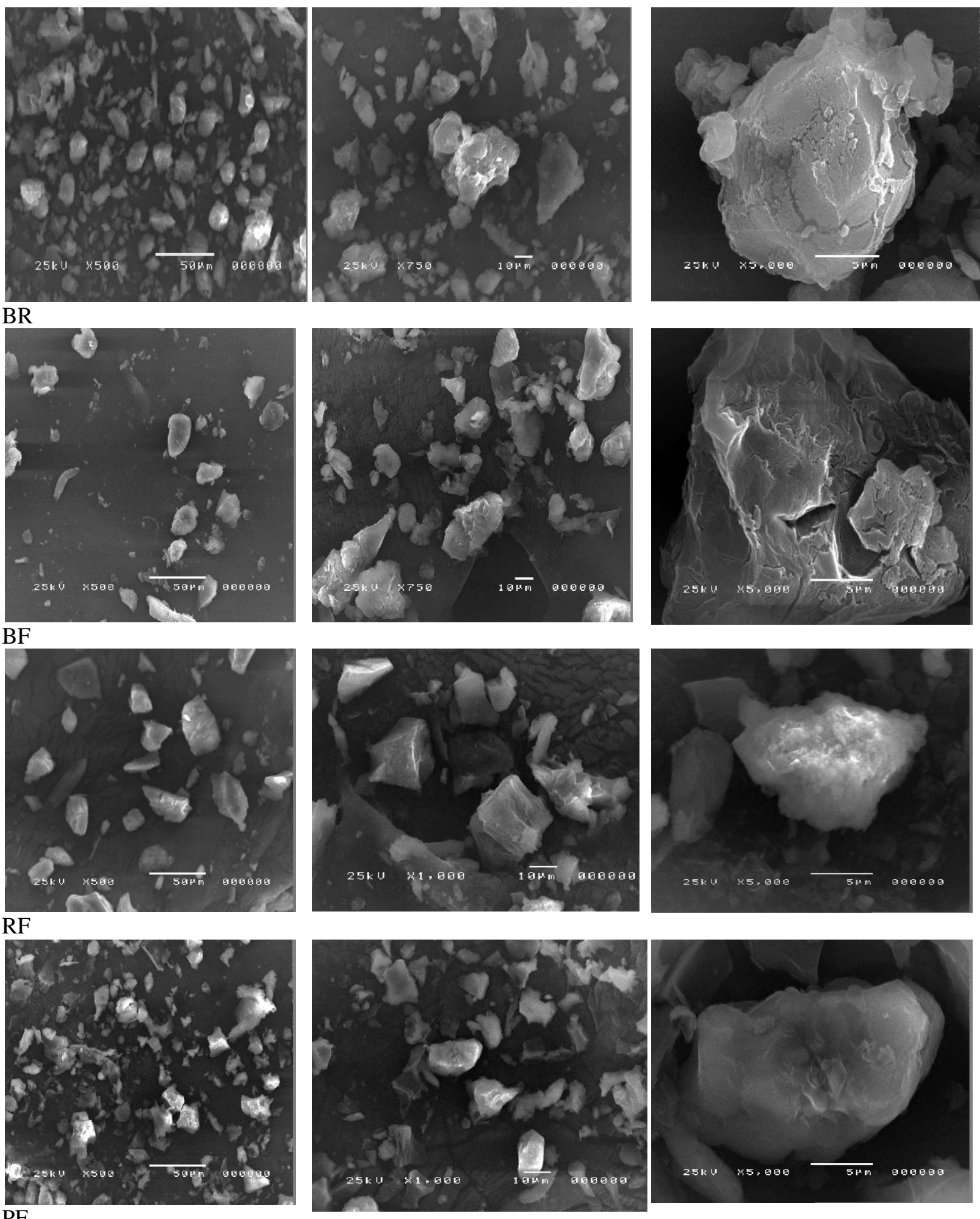

$\mathrm{PF}$

Fig. (1). Scanning Electron Microscopic (SEM) Examination of rice flours $B R F$ - broken rice flour, BF- pressured parboiled broken rice flour, $R F$ - dry roasted parboiled broken rice Flour, PF- popped broken rice flour. 
Table (1). Chemical composition of broken rice flour, untreated and hydrothermal treated gluten - free rice papers on dry weight basis.

\begin{tabular}{|c|c|c|c|c|c|c|c|}
\hline Samples & $\begin{array}{l}\text { Protein } \\
\text { (g/ 100g) }\end{array}$ & $\begin{array}{c}\text { Fat } \\
(\mathrm{g} / \mathrm{100g})\end{array}$ & $\begin{array}{c}\text { Ash } \\
(\mathrm{g} / \mathrm{100g})\end{array}$ & $\begin{array}{c}\text { Crude fiber } \\
\text { (g/ 100g) }\end{array}$ & $\begin{array}{c}\text { Total starch } \\
(\mathrm{g} / \mathrm{100g})\end{array}$ & $\begin{array}{l}\text { Amylose } \\
\text { (g/ 100g) }\end{array}$ & $\begin{array}{c}\mathrm{SD}^{*} \\
\text { (g glucose/ } \\
\mathbf{1 0 0 g} \text { ) }\end{array}$ \\
\hline BRF & $7.40 \pm 0^{\mathrm{a}}$ & $0.47 \pm 0^{d}$ & $0.49 \pm 0.02^{\mathrm{e}}$ & $0.73 \pm 0.02^{\mathrm{a}}$ & $84.81 \pm 0.02^{\mathrm{a}}$ & $15.27 \pm 0.3^{\mathrm{c}}$ & $37.7 \pm 0.1^{\mathrm{e}}$ \\
\hline $\mathrm{C}$ & $6.7 \pm 0.06^{b}$ & $1.67 \pm 0.06^{c}$ & $1.62 \pm 0.04^{d}$ & $0.27 \pm 0.02^{b c}$ & $81.67 \pm 0.51^{b}$ & $17.27 \pm 0.3^{\mathrm{a}}$ & $80 \pm 0.4^{\mathrm{d}}$ \\
\hline B & $4.33 \pm 0.27^{\mathrm{d}}$ & $1.73 \pm 0^{b}$ & $2.37 \pm 0.02^{b}$ & $0.24 \pm 0.02^{c}$ & $76.62 \pm 0.3^{d}$ & $15.67 \pm 0.03^{b}$ & $85.6 \pm 0.8^{c}$ \\
\hline $\mathbf{R}$ & $5.58 \pm 0.01^{\mathrm{c}}$ & $1.8 \pm 0.01^{\mathrm{a}}$ & $2.2 \pm 0.08^{\mathrm{c}}$ & $0.29 \pm 0.01^{b}$ & $79.43 \pm 0.02^{\mathrm{c}}$ & $14.28 \pm 0.03^{d}$ & $99.73 \pm 1.4^{\mathrm{a}}$ \\
\hline $\mathbf{P}$ & $3.57 \pm 0.32^{\mathrm{e}}$ & $1.82 \pm 0.01^{\mathrm{a}}$ & $2.68 \pm 0.01^{a}$ & $0.24 \pm 0.01^{c}$ & $76.36 \pm 0.37^{d}$ & $14.18 \pm 0.1^{\mathrm{d}}$ & $90.86 \pm 0.90^{b}$ \\
\hline
\end{tabular}

* SD: starch digestibility

BRF- broken rice flour, $\mathrm{C}$ - untreated rice paper, B- pressured parboiled rice paper, $\mathrm{R}$ - dry roasted parboiled rice paper, $\mathrm{P}$ - popped rice paper. Data are presented as means \pm SDM $(n=3) \&$ Means within a column with different letters are significantly different at $P \leq 0.05$.

Nessreen et al. (2014) found that the Egyptian rice variety Sakha 104 (Japonica genotype) had $7.25 \%$ protein, $0.45 \%$ fat, $0.50 \%$ ash, $0.66 \%$ crude fiber, and $18.20 \%$ amylose, which is close to our results.

Regarding rice paper produced from untreated flour, Nagano et al. (2000) found that the Japanese rice paper produced from low-amylose rice (Akebono variety) had $6.94 \%$ crude protein, and $17.52 \%$ amylose, which is close to our results. For rice papers produced from hydrothermal treated flours, a significant decrease was found in protein, total starch, and amylose contents . While, a significant increase was found in fat and ash contents. However, crude fiber was not affected. The decrease in protein might imparted by heat denaturation, forming starch- protein complex, and adhesion/ cohesion of proteins with other components (Buggenhout et al., 2013). Besides, the formation of melanoidin compounds in Maillard reaction between reducing sugars from the heated starch and the amino group in the proteins on high heat processing (Dutta et al., 2015). The decrease in total starch and amylose contents is attributed either to the leaching out of starch and amylose into the soaking water (Patindol et al., 2008), or the more severe the processing condition/ gelatinization process, the more rapid the digestion of starch, the more decrease in soluble amylose (Jorgen et al., 1987; Chitra et al., 2010).

The increase in fat content is imparted by the leaching and rupturing of the fat globules during the hydrothermal treatment (Pathmanathapillai et al., 2016) and the addition of corn oil to the batter.
The increase in ash content is due to the addition of salt in the batter (Phothiset and Charoenrein, 2007), it was more evident in popped rice paper because of the conditioning in salt.

3.3. In vitro starch digestibility of broken rice flour and untreated and hydrothermaltreated gluten - free rice papers

In vitro starch digestibility results (g glucose / $100 \mathrm{~g}$ sample) are presented in Table (1). Data revaled low in vitro starch digestibility of broken rice flour and rice paper produced from untreated flour. This may be due to the native structure of the starch which is semi-crystalline in nature; where the starch granule is usually surrounded by a protein matrix making it less susceptible to enzymatic digestion (Deepa et al., 2010). On the other hand, in vitro starch digestibility significantly increased in rice papers produced from hydrothermal treated flours, and the most significant increase was pronounced more in dry roasted parboiling treatment followed by popped one. This may be attributed to that soaking in hot water and pressure cooking causes significant increase in starch digestibility (Rosario and Jayashree, 2000), where the starch gelatinization has taken place, accompanied with molecular breakdown resulted in higher exposure of the starch fractions to the digestive enzymes (Dutta et al., 2015), and with the increase in the degree of parboiling, the digestibility increased (Chitra et al., 2010). The reason for a low digestibility shown by popped rice paper,was probably due to that tempering in salt, followed by popping with hot air convection, helped in the formation of resistance starch (Vaidya and Sheth, 2011). This 
resistant form of starch is considered dietary starch, that resists the digestion and give a lower digestibility than dry roast parboiling treatment (Kumar and Prasad, 2013).

\subsection{Viscoelastic properties of gluten-free rice paper batters}

Viscoelastic properties of gluten-free rice paper batters are presented in Fig. (2). It could be seen that an apparent viscosity of rice paper batters was decreased with increasing shear rates, revealing the non-Newtonian pseudoplastic or shearthinning behavior of the batters and could be modeled as power law- fluid $\left(n=\mathrm{kr}^{\mathrm{n}-1}\right)$. The increased shear rate deforms and rearranges starch particles, resulting in a lower flow resistance and consequently a lower apparent viscosity (Xue and Ngadi, 2006). Decreased apparent viscosity is beneficial for spreading the rice batter as well as giving a suitable texture to rice paper (Phattra and Maweang, 2015). Another concern, is that the hydrothermal treated rice papers batter had a higher apparent viscosity than untreated sample. This is attributed to the fact that the hydrothermal treatment caused swelling of starch granules, released soluble components and amylose, absorbed more water, thus decreased the free available water in the system and developed more apparent viscosity than untreated rice paper batter (Rohaya et al., 2013). Kuenchan et al. (2009) indicated that gelatinized starch showed higher swelling power and possessed more consistency and apparent viscosity than native rice starch.

\subsection{Color measurements of gluten-free rice papers}

Table (2) shows the color measurements of gluten- free rice papers produced from untreated and hydrothermal- treated flours. Data revealed significant reduction in lightness value $\left(L^{*}\right)$ in the dry roasted parboiled and popped treatments. This reduction was due to starch gelatinization (Dutta and Mahanta, 2012 ; Dutta et al., 2015). Islam et al. (2004) reported that lightness value is directly correlated with the extent of gelatinization during parboiling, besides time and temperature of soaking, heating, and drying (Hapsari et al., 2016). From the same Table significant increase in positive values of $a^{*}$ (redness), and $b^{*}$ (yellowness), was observed in all hydrothermal treatments. This is imparted by Maillard browning on high heat processing between reducing sugar from the heated starch, and the amino group of the
Table (2). Color measurements of untreated and hydrothermal treated gluten - free rice papers.

\begin{tabular}{|l|c|c|c|}
\hline Samples & $L^{*}$ & $a^{*}$ & $b^{*}$ \\
\hline C & $89.77 \pm 0.24^{\mathrm{a}}$ & $0.33 \pm 0.04^{\mathrm{c}}$ & $3.75 \pm 0.07^{\mathrm{d}}$ \\
\hline B & $\mathbf{7 4 . 7 7 \pm 0 . 5 1 ^ { \mathrm { b } }}$ & $\mathbf{0 . 3 7} \pm 0.16^{\mathrm{b}}$ & $\mathbf{5 . 5 8} \pm 0.21^{\mathrm{c}}$ \\
\hline R & $68.6 \pm 1.26^{\mathrm{c}}$ & $\mathbf{0 . 5 4} \pm 0.02^{\mathrm{b}}$ & $\mathbf{7 . 6 4} \pm 0.07^{\mathrm{b}}$ \\
\hline P & ${\mathbf{6 0 . 4 2} \pm 2.27^{\mathrm{d}}}^{\mathrm{d}}$ & $\mathbf{1 . 5 4} \pm 0.47^{\mathrm{a}}$ & $\mathbf{2 0 . 5 9} \pm 1.62^{\mathrm{a}}$ \\
\hline
\end{tabular}

$\mathrm{L}^{*}=$ lightness $(0=$ black, $100=$ white $), \mathrm{a}^{*}\left(-\mathrm{a}^{*}=\right.$ greenness, $+\mathrm{a}^{*}=$ redness $)$ and $b^{*}\left(-b^{*}=\right.$ blueness, $+b^{*}=$ yellowness $)$.

$\mathrm{C}$ - untreated rice paper, B- pressured parboiled rice paper, R-dry roasted parboiled rice paper, $\mathrm{P}$ - popped rice paper.

Data are presented as means $\pm \operatorname{SDM}(n=3) \&$ Means within a column with different letters are significantly different at $P \leq 0.05$.

proteins, during modification (Takahashi et al., 2005; Lamberts et al., 2006; Lorlowhakarn and Naivikul, 2006).

\subsection{Mechanical properties of gluten-free rice papers}

The mechanical properties of gluten-free rice papers are presented in Table (3).

Table (3). The mechanical properties of gluten- free rice papers.

\begin{tabular}{|c|c|c|c|}
\hline Samples & $\begin{array}{c}\text { Tensile } \\
\text { strength } \\
\left(\mathrm{N} / \mathbf{m m}^{2}\right)\end{array}$ & $\begin{array}{c}\text { Elongation } \\
(\%)\end{array}$ & $\begin{array}{l}\text { Fracture } \\
\text { toughness } \\
\left(\mathrm{N} / \mathrm{mm}^{3 / 2}\right)\end{array}$ \\
\hline C & $0.14 \pm 0.08^{c}$ & $43 \pm 0.07^{c}$ & $\begin{array}{c}3.64 \\
\pm 0.25^{b}\end{array}$ \\
\hline B & $0.34 \pm 0.07^{\mathrm{a}}$ & $48 \pm 0.13^{b}$ & $2.93 \pm 0.24^{\mathrm{c}}$ \\
\hline $\mathbf{R}$ & $0.36 \pm 0.13^{a}$ & $57 \pm 0.19^{a}$ & $2.76 \pm 0.23^{c}$ \\
\hline $\mathbf{P}$ & $0.16 \pm 0.05^{b}$ & $43 \pm 0.05^{c}$ & $5.51 \pm 0.17^{\mathrm{a}}$ \\
\hline
\end{tabular}

C- untreated rice paper, B- pressured parboiled rice paper, $R$ - dry roasted parboiled rice paper, $P$ - popped rice paper Data are presented as means \pm SDM $(n=5)$ \& Means within a column with different letters are significantly different at $P<0.05$.

The data revealed that tensile strength, which assessed the maximum stress that the rice paper can support (Detduangchan et al., 2014), significantly increased in rice papers produced from hydrothermal treatments. These results indicated that the treated rice papers exhibited proper mechanical strength. This ensures its integrity and the resistance to fracture and cracks especially, during storage and reduces the defects, such as pinholes or fissures (Guilbert et al., 1995; Chayapham et al., 2008; Bertuzzi et al., 2012). This might be relates to the use of the gelatinized 


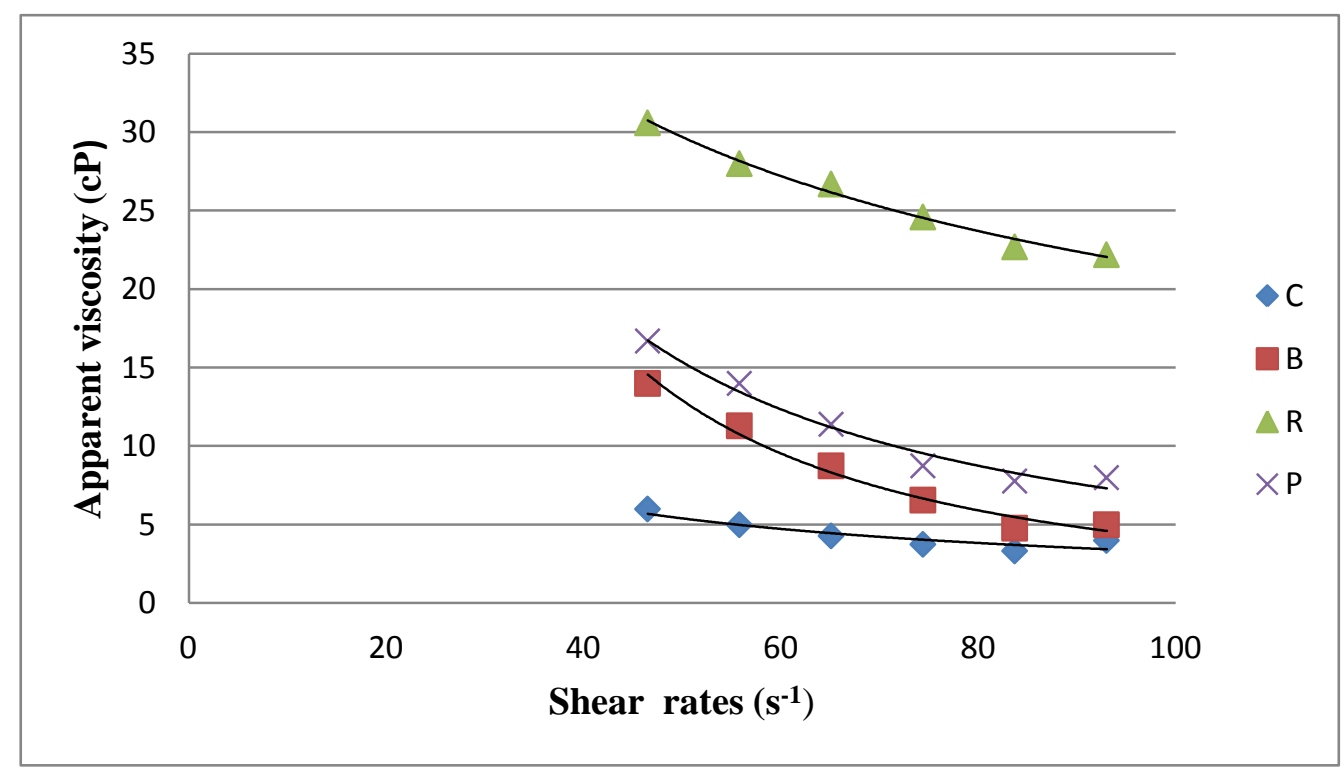

Fig. (2). Apparent viscosity of the gluten- free rice paper batters at different shear rates. C- untreated rice paper, B- pressured parboiled rice paper, R- dry roasted parboiled rice paper, P- popped rice paper.

flour obtained by the hydrothermal treatments, which causes starch retrogradation (CabreraChávez et al., 2012) coupled with the interaction between rice flour and corn starch as a polysaccharide or polymer useful to improve the mechanical properties (Loubes et al., 2016).

One of the most remarkable features of good rice paper is a high elasticity (Phattra and Maweang, 2015), the elongation at break (\%) which expresses the ability of a material to resist changes of shape without crack formation (ASTM, 2010) increased much significant in pressured parboiled and dry roasted parboiled treatments. These results meaning the guarantees of adequate viscous, elastic and flexibility properties of these rice paper samples to possible deformation without breaking during filling (Bertuzzi et al., 2012). On the other hand, the fracture toughness which measures the energy required to cause fracture (Sim et al., 1993) was significantly decreased in both parboiled treatments and increased in popped treatment. This might be related to the massive temperature used in popping treatment followed by rapid drying that increased the hardness of the rice paper, in turn, it absorbed more energy and consequently required a greater energy input to create fractures (Fellows, 2000).

\subsection{Sensory evaluation of gluten-free rolled rice papers}

Table (4) represents the sensory evaluation of gluten-free rolled papers. Statistical analysis showed that there were some significant sensory differences between the rolled rice papers produced from untreated and hydrothermaltreated flours $(P \leq 0.05)$.

The differences in color between untreated and treated rice papers are attributed to the changes in color values as mentioned before.

The dry roasted parboiled and pressured parboiled rice papers were greatly improved in freshness and rollability when compared to the untreated rice papers. The improvement occurred in rollability might be due to the significant increase in elongation at break (\%) as mentioned in the mechanical properties.

Taste, aroma, and firmness of the dry roasted parboiled rice paper received higher ratings; however, it did not differ significantly when compared to untreated rice paper. On the other hand, popped rice paper received the least score and this might be due to the use of high temperature during the modification, this increased the toughness, in turn, decreased the firmness and freshness, as well as the rollability. 
Table (4). Sensory evaluation of gluten-free rolled rice papers.

\begin{tabular}{|c|c|c|c|c|c|c|c|}
\hline Samples & color & taste & aroma & firmness & freshness & rollability & OAA* \\
\hline $\mathbf{C}$ & $8.54 \pm 0.8^{b}$ & $8.18 \pm 0.9^{a}$ & $8.36 \pm 0.8^{a}$ & $8.64 \pm 0.5^{a}$ & $7.77 \pm 1^{c}$ & $7.82 \pm 1^{b}$ & $7.73 \pm 1.1^{b}$ \\
\hline B & $8.18 \pm 1^{c}$ & $8.36 \pm 0.8^{\mathrm{a}}$ & $8.1 \pm 1.1^{a}$ & $7.59 \pm 1^{b}$ & $8.55 \pm 0.5^{\mathrm{ab}}$ & $8.68 \pm 0.6^{a}$ & $8.41 \pm 0.7^{a}$ \\
\hline $\mathbf{R}$ & $8.63 \pm 0.7^{a}$ & $8.45 \pm 0.7^{\mathrm{a}}$ & $8.63 \pm 0.5^{\mathrm{a}}$ & $8.73 \pm 0.5^{\mathrm{a}}$ & $8.82 \pm 0.4^{a}$ & $8.82 \pm 0.4^{\mathrm{a}}$ & $8.45 \pm 0.7^{\mathrm{a}}$ \\
\hline $\mathbf{P}$ & $7.59 \pm 0.8^{d}$ & $7.63 \pm 1.2^{b}$ & $8.14 \pm 1^{a}$ & $6.95 \pm 1.6^{b}$ & $7.68 \pm 1.6^{c}$ & $7.27 \pm 0.9^{b}$ & $7.41 \pm 0.9^{\mathrm{bc}}$ \\
\hline
\end{tabular}

The overall scores of the sensory aspects of dry roasted parboiled and pressured parboiled rice papers were preferred over the untreated rice paper.

\section{Conclusion}

Rice papers produced from pressure parboiled, dry roasted parboiled, and popped broken rice flours were compared to rice paper produced from native broken rice flour, in term of morphological, physicochemical, and sensory properties. The morphology of the treated broken rice flour demonstrated gelatinized and developed starch granules, with various shapes and cracks, particularly in dry roasted parboiled one. Rice papers obtained from hydrothermal treated broken rice flours had lower protein, starch and amylose contents, and higher fat, ash, and in vitro starch digestibility compared to rice paper obtained from native broken rice flour. Apparent viscosity of the treated rice paper slurry had a non-Newtonian shear-thinning behavior, modeled as a power law fluid. Not only, the parboiling techniques increased the elasticity and resistance to longitudinal stress of the rice papers, but also, they achieved the highest sensory hedonic score. Popped technique increased the energy required to fracture the rice paper, but it achieved the lowest sensory hedonic score. The results of the present study could be useful in improvement of rice paper processing via parboiling and popping techniques. Besides, it added value for those concerned about gluten- free products.

\section{REFERENCES}

AOAC (2007). Association of Official Analytical Chemist. Official methods of analysis. $\left(18^{\text {th }}\right.$. ed). Washington, DC, USA.

Ashour E.A., Reda F.M. and Alagawany M. (2015). Effect of graded replacement of corn by broken rice in growing Japanese quail diets on growth performance, carcass traits and economics. Asian J. Anim. Sci., 9 (6): 404- 411.

ASTM (2010). American Society for Testing Materials, Standard Test Method for Tensile Properties of Thin Plastic Sheeting, ASTM D882-88 of Materials, Annual Book of ASTM. Standard, Philadelphia. p. 182-190.

Bertuzzi M.A., Gottifredi J.C., and Armada M. (2012). Mechanical properties of a high amylose content corn starch based film, gelatinized at low temperature. Braz. J. Food Tech., 15: 219- 227.

Bhatnagar A.S., Prabhakar D.S., Kumar P.K., Raja Rajan R.G. and Krishna G.A.G. (2014). Processing of commercial rice bran for the production of fat and nutraceutical rich rice brokens, rice germ and pure bran. LWT Food Sci. Tech., 58, 306- 311.

Bhattacharya K. (2004). Parboiling of rice. In: Rice Chemistry and Technology, Elaine, T. (Ed.). American Association of Cereal Chemists, Inc, St. Paul, Minnesota,USA. pp. 329-394.

Bhattacharya K.R. and Ali S.Z. (1985). Changes in rice during parboiling and properties of parboiled rice. In: Adv. Cereal Sci. Tech.,vol. 7. AACC. Inc, St. Paul, Minnesota, pp.105-167.

Brookfield Manual (1998) Brookfield Manual Operating Instruction. No. M/98-211B0104. Brookfield Engineering Laboratories Inc., Middleborough.

Buggenhout J., Brijs K. and Delcour, J.A. (2013). Impact of processing conditions on the extractability and molecular weight distribution of proteins in parboiled brown rice. J. Cereal Sci., 58: 8- 14. 
Cabrera-Chávez F., Calderón de la Barca A.M., Islas-Rubio A.R., Marti A., Marengo M., Pagani M.A., Bonomi F. and Iametti S. (2012). Molecular rearrangements in extrusion processes for the production of amaranth-enriched, gluten- free rice pasta. LWT- Food Sci. Tech., 47: 421- 426.

Cameron S.J. and Hosseinian F. (2013). Potential of flaxseed in the development of omega-3 rice paper with antioxidant activity. LWT Food Sci. Tech., 53:170-175.

Cham S. and Suwannaporn P. (2010). Effect of hydrothermal treatment of rice flour various rice noodles quality. J. Cereal Sci., 51 (3): 284-291.

Chang Sh. and Yang H. (1992). Thermal processing effects on rice characteristics. Food Structure: 2: 373- 382.

Chayapham O., Uttapap D., Puttarnlek Ch. and Rungsardthong V. (2008). Improvement of rice paper quality by mixing rice flour with canna starch. Kmutt Res. Develop. J., 31: 245- 260.

Chinnaswamy R. and Bhattacharya K.R. (1986). Pressure parboiled rice-A new base for making expanded rice. J. Food Sci. Tech., 23:1-6.

Chitra M., Singh V. and Ali S.Z. (2010). Effect of processing paddy on digestibility of rice starch by in vitro studies. J. Food Sci. Tech. , 47(4): 414- 419.

Colussi, R., Pintoa, V.Z., El Halal, S. L.M. et al. (2014). Structural, morphological, and physicochemical properties of acetylated high-, medium-, and low-amylose rice starches. Carbohydrate Polymers, 103: 405413.

Deepa G., Singh V. and Naidu K. A. (2010) . A comparative study on starch digestibility, glycemic index and resistant starch of pigmented ('Njavara' and 'Jyothi') and a non - pigmented ('IR 64') rice varieties. J. Food Sci. Tech., 47: 644- 649.

Detduangchan N., Sridach W. and Wittaya T. (2014). Enhancement of the properties of biodegradable rice starch films by using chemical crosslinking agents. Inter. Food Res. J., 21: 1225- 1235.

Dronzek B.L., Wang P.H. and Bushuk W. (1972). Scanning electron microscopy of starch from sprouted wheat. Cereal Chem., 49(1): 232- 239 .

Dutta H. and Mahanta, C. L. (2012). Effect of hydrothermal treatment varying in time and pressure on the properties of the parboiled rice with different amylose content. Food Rese Inter.1, (49): 655- 663.

Dutta H., Mahanta C.L. and Singh, V. (2015). Changes in the properties of rice varieties with different amylose content on dry heat parboiling. J. Cereal Sci., 65: 227- 235.

El-Hissewy A.A., El-Kady A.A. and Lásztity R.L. (1992). A study on the cooking and eating quality characteristics of some Egyptian rice varieties. Periodica Polytech.Chem. Eng., 36: 3-11.

Englyst H.N., Kingman S.M. and Cummings J.H. (1992). Classification and measurement of nutritionally important starch fractions. Euro. J. Clin. Nutr., 46, S33- S50.

Fellows P. (2000). Processing Technology Principles and Practice. $2^{\text {nd. }}$ Edition, Woodhead Publishing Limited and CRC Press LLC, Washington DC.USA.

Guilbert S., Gontard N. and Cuq B. (1995). Technology and applications of edible protective films. Pack. Tech. Sci.,8: 339346.

Hapsari A.H., Kim S-J. and Eun J-B. (2016). Physical characteristics of parboiled Korean glutinous rice (Olbyeossal) using a modified method. LWT - Food Sci. Tech., 68: 499- 505.

Hsieh F. and Bor S.L. (1991). Breakfast rice cereals and baby foods - Rice snack foods. In: Rice utilization, $2^{\text {nd }}$. ed, Bor SL (ed). Van Nostrand Rienhold, New York, USA, Vol 2, pp 177-194: 225-249.

Islam M.R., Shimizu M. and Kimura T. (2004). Energy requirement in parboiling and its relationship to some important quality indicators. J. Food Eng. 63: 433- 439.

Jobling S. (2004). Improving starch for food and industrial applications. Curr. Opin. in Plant Biology, 7: 210- 218.

Jorgen H., Barbro H., Inger B. and Ann-Charlotte I. (1987) The effect of various thermal processing on the glycemic response to whole grain wheat in human and rats. J. Nut., 119:1631- 1638. 
Juliano B.O. (1971). A simplified assay for milled rice amylose. Cereal Sci. Today, 16: 334360.

Kuenchan N.N., Taewee T. and Piyarat, S. (2009). Crystallinity and rheological properties of pregelatinized rice starches differing in amylose content. Starch, 61: 101- 108.

Kumar S. and Prasad K. (2013). Effect of paddy parboiling and rice puffing on physical, optical and aerodynamic characteristics. Inter. J. Food Sci. Tech., 4: 765- 770.

Lamacchia C., Camarca A., Picascia S., Di Luccia A. and Gianfrani C. (2014). Cereal-based gluten-free food: how to reconcile nutritional and technological properties of wheat proteins with safety for celiac disease patients- a review. Nutr., 6: 575- 590.

Lamberts L., Brijs K., Mohamed R., Verhelst N. and Delcour J.A. (2006). Impact of browning reactions and bran pigments on color of parboiled rice. J. Agric. Food Chem. , 54:9924- 9929.

Lebwohl B., Ludvigsson J.F. and Green P.H.R. (2015). Celiac disease and non-celiac gluten sensitivity. BMJ, 351: h4347.

Limberger V.M., Silva L.P., Emanuelli T., Comarela C.G. and Patias L.D. (2008). Physical and chemical modification of starch from broken rice for use in the food industry. New Chemical, 31:84-88.

Livingstone A.S., Feng J.J. and Malleshi N.G. (1993). Development and nutritional quality evaluation of weaning foods based on malted, popped and dried wheat and chickpea. Inte.J Food Sci. Tech., 28: 35- 43.

Lorlowhakarn K. and Naivikul O. (2006). Modification of rice flour by heat moisture treatment (HMT) to produce rice noodles. Kasetsart J. (Natural Science), 40 (Suppl.): 135- 143.

Loubes M.A., Flores S.K. and Tolaba M.P. (2016). Effect of formulation on rice noodle quality: Selection of functional ingredients and optimization by mixture design. LWT Food Sci Techn.,69:280- 286.

Marco M.De., Peiretti P.G., Miraglia N. and Bergero D. (2014). Apparent digestibility of broken rice in horses using in vivo and in vitro methods. Animal , 8: 245- 249.
McGurie R.G. (1992). Reporting of objective color measurements. HortScience, 27: 1254-1255

Mir S.A., Bosco S.J.D. (2013). Effect of soaking temperature on physical and functional properties of parboiled rice cultivars grown in temperate region of India. Food Nut. Sci.,4: 282- 288.

Mishra G., Joshi D.C. and Panda B.K. (2014). Popping and puffing of cereal grains- a review. J. Grain Process.Storage, 1: 34- 46.

Murray J.A., Watson T., Clearman B. and Mitros F. (2015). Effect of a gluten-free diet on gastrointestinal symptoms in celiac disease. Amer J. Clinical Nutr., 79: 669- 673.

Nagano H., Shoji Z., Tamura A., Kato M., Omori M. and To K., Dang T. and Le N. (2000). Some characteristics of rice paper of Vietnamese traditional food (Vietnamese spring rolls)- a note. Food Sci. Tech. Res., 6(2): 102-105.

Nessreen N.B., Ammar A.K. and Ezzat A. (2014). Study of some cooking and eating quality characters on some Egyptian rice genotypes. Agric. Sci. Publ .159: 77- 82.

Oko A.O., Ubi B.E. and Dambaba N. (2012). Rice cooking quality and physico-chemical characteristics- a comparative analysis of selected local and newly introduced rice varieties in Ebonyi State, Nigeria. Food Public Health, 2: 43- 49.

Pathmanathapillai D., Prabhaharan M. and Balakumar S. (2016). Effects of the various parboiling methods on the proximate composition, amylose and resistant starch of two rice varieties from Sri Lanka. Imperial J. Interdisciplinary Res., 2: 295- 300.

Patindol J., Newton J. and Wang Y.J. (2008). Functional properties as affected by laboratory scale parboiling of rough rice and brown rice. J. Food Sci., (73): 370- 377.

Phattra B. and Maweang M. (2015). Effects of natural fermentation on the rice slurry properties related to rice paper production. J. Food Sci. Agric. Tech., 1: 22- 25.

Phothiset S. and Charoenrein S. (2007). Morphology and physicochemical changes in rice flour during rice paper production. Food Res. Inter., 40: 266- 272. 
Pitiphunpong S. and Suwannaporn P. (2009). Physicochemical properties of KDML 105 rice cultivar from different cultivated location in Thailand. J.Sci. Food Agric.,89: 2186- 2190.

Rohaya M.S., Maskat M.Y. and Ma'aruf A.G. (2013). Rheological properties of different degree of pregelatinized rice flour batter. Sains Malaysiana, 42: 1707- 1714.

Rosario S. and Jayashree A. (2000). Effect of domestic processing methods on the starch, non-starch polysaccharide and in vitro starch and protein digestibility of three varieties of rice with varying level of amylose. Food Chem., 70:107- 111.

Rosell C.M., Barro F., Sousa C. and Mena M.C. (2014). Cereals for developing gluten-free products and analytical tools for gluten detection. J. Cereal Sci., 59: 354-364.

SAS. (1996). SAS/STAT1 user's guide, version 8. Cary, NC: SAS Inst, Inc.

Shashikala I.S., Vasudeva S. and Ali S.Z. (2005). Changes in physicochemical properties of Basmati paddy upon parboiling. Trends in Carbohydrate Chemistry, 9: 53- 59.

Shittu T.A., Olaniyi M.B., Oyekanmi A.A. and Okeleye K.A. (2012). Physical and water absorption characteristics of some improved rice varieties. Food Bioproc. Tech., 5:298309.

Sim B.J., Lucas P.W., Pereira B.P. and Oates C.G. (1993). Mechanical and sensory assessment of the texture of refrigerator-stored spring roll pastry. J. Text. Studies, 24: 27- 44.

Takahashi T., Miura M., Ohisa N., Mori K. and Kobayashi S.(2005). Heat treatments of milled rice and properties of the flours. Cereal Chem., 82: 228- 232.

Vaidya R.H. and Sheth M.K. (2011). Processing and storage of Indian cereal and cereal products alters its resistant starch content. J. Food Sci. Tech., 48: 622- 627.

Wongsa J., Uttapap D., Lamsal B.P. and Rungsardthong V. (2016). Effect of puffing conditions on physical properties and rehydration characteristic of instant rice product. Inter. J. Sci. Tech., 51: 672- 680.

Xue J. and Ngadi M. (2006). Rheological properties of batter systems formulated using different flour combination. J. Food Eng., 77: 334- 341.

Zhu L.J., Liu Q.Q., Sang Y.J., Gu M.H. and Shi Y.C. (2010). Underlying reasons for waxy rice flours having different pasting properties. Food Chem., 120:94-100.

إنتاج لفائف جلاش خالية من الجلوتين من كسر الأرز باستخدام معاملات حرارية مختلفة

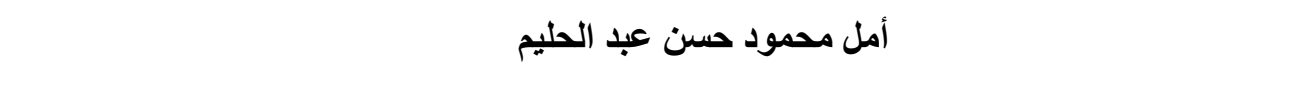

قسم بحوث تكنولوجيا المحاصيل ـ معهد بحوث تكنولوجيا الأغذيةـ مركز البحوث الزر اعيةـ الجيزةـ مصر.

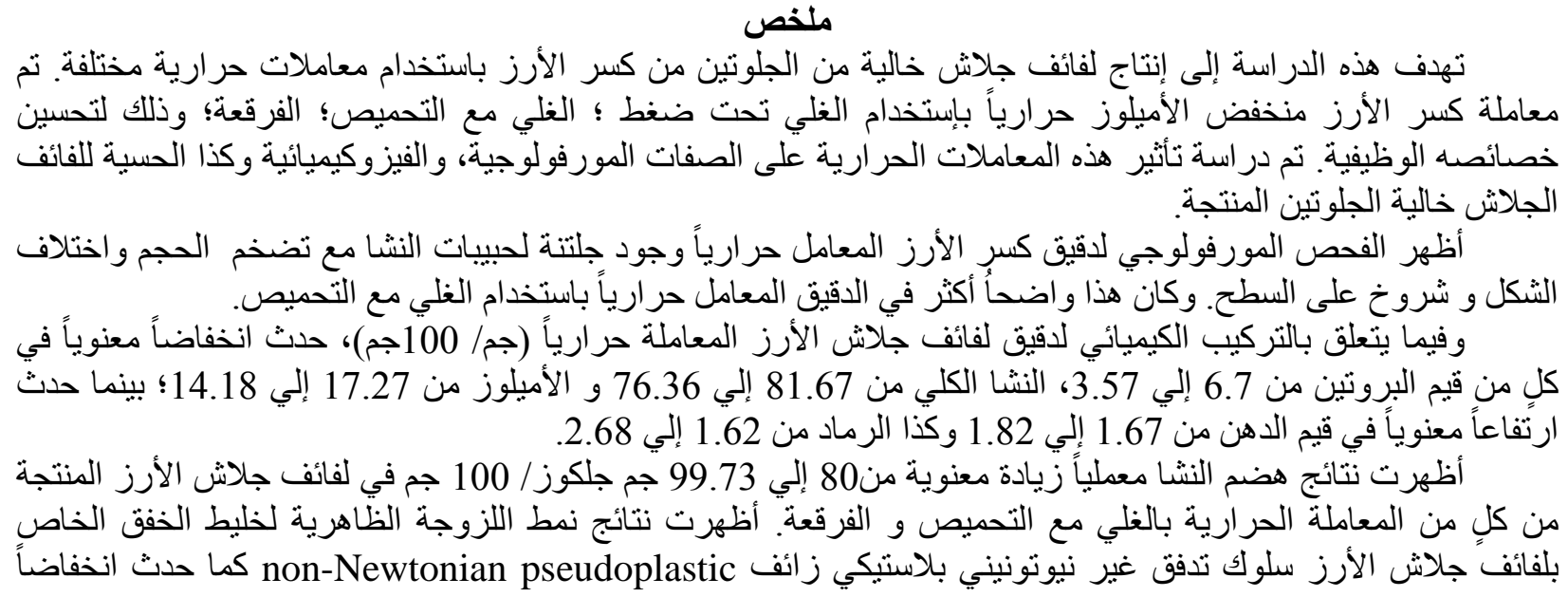




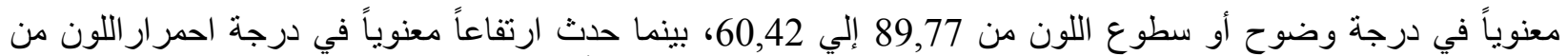

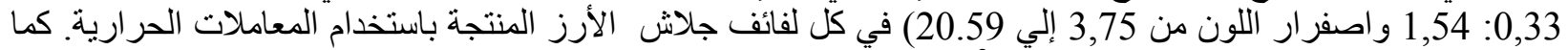

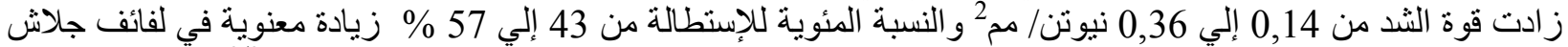

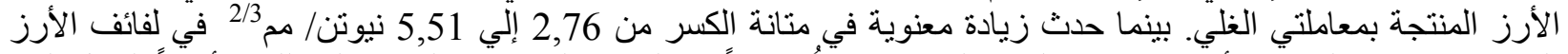

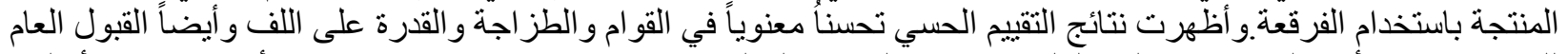

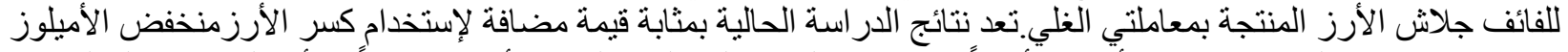
في تحسن تصنيع لفائف جلاش الأرز و أيضاً تقديم هذا المنتج إلى المستهلكين الأكثر اهتماماً بشأن المنتجات الخات الخالية من الجلوتين.

$$
\text { المجلة العلمبية لكلية الزراعة - جامعة القاهرة - المجلد (67) العلد/اثثانى (أبريل 2016:) } 167 \text { - } 179 \text { ـ }
$$

